\title{
STUDI PENDAHULUAN PENGGUNAAN BAKTERI Flavimonas BY-9 SEBAGAI PROBIOTIK DALAM PEMELIHARAAN LARVA UDANG WINDU Penaeus monodon
}

\author{
Haryanti ${ }^{*}$, Samuel Lante ${ }^{*)}$ dan S. Tsumura ${ }^{* *}$
}

\begin{abstract}
ABSTRAK
Mortalitas larva yang masih tinggi karena ketidakseimbangan kondisi lingkungan dan serangan penyakit menyebabkan rendahnya produksi dan mutu benur.

Penelitian penggunaan bakteri sebagai probiotik telah dilakukan dalam pemeliharaan larva udang $P$. monodon. Tujuan utama penelitian ini adalah meningkatkan keragaan pertumbuhan dan sintasan larva udang. Bakteri diisolasi dari perairan pantai Gondol (Bali) dan Banyuwangi (Jawa Timur). Setelah melalui pemurnian berulangkali dan pengujian, ternyata satu isolat bakteri (code BY-9) yang termasuk dalam genus Flavimonas dapat digunakan sebagai probiotik dalam pemeliharaan larva udang. Perlakuan dalam penelitian ini adalah dengan menginokulasi bakteri dalam media pemeliharaan larva udang dan tanpa inokulasi bakteri (kontrol), masingmasing dengan 6 kali ulangan.
\end{abstract}

Hasil yang diperoleh menunjukkan bahwa pertumbuhan dan sintasan larva udang pada perlakuan yang diinokulasi dengan bakteri BY-9 berbeda nyata $(P<0,05)$ dibandingkan kontrol.

\section{ABSTRACT: Preliminary study on the use of bacteria Flavimonas BY-9 as probiotic in larval rearing of Penaeus monodon. By: Haryanti, Samuel Lante and S. Tsumura.}

High mortality of larva has been argued caused by environmental degradation and diseases. These facts could affect production and performance of fry.

The use of bacteria as probiotic in the rearing of $P$. monodon larvae was studied. The main purpose of this study was to improve growth performance of shrimp larvae. Bacteria as probiotic agent were isolated from the coastal waters of Gondol (Bali) and Banyuwangi (East Java). One isolate of bacteria Flavimonas BY-9 showed the characteristics of probiotic agent. This bacteria was inoculated to the rearing water of $P$. monodon larvae in the laboratory. Two treatments were applied i.e. inoculation of bacteria Flavimonas BY-9 in the larval culture and control (without bacteria inoculation).

Results of experiment showed that the growth and survival rates of shrimp larvae inoculated by bacteria Flavimonas BY-9 were significantly greater than the uninoculated larvae $(P<0.05)$.

KEYWORDS: Probiotic bacteria, Penaeus monodon, Flavimonas.

\section{PENDAHULUAN}

Dewasa ini pola budidaya udang di Indonesia sudah berkembang sangat pesat, sehingga diperlukan benih yang memadai untuk memenuhi kebutuhan tersebut. Oleh karena itu, sistem pembenihan secara intensif banyak dipraktekkan. Sistem ini seringkali menekankan pada penggunaan padat penebaran larva dan masukan bahan organik yang tinggi. Di samping itu, juga dilakukan penggunaan antibiotik dan terapi kimiawi yang tidak terkendali dengan dosis dan frekuensi yang berlebihan. Dampak dari aktivitas ini menyebabkan gangguan pada keseimbangan dinamika alami mikroorganisme dan perubahan lingkungan dalam pemeliharaan larva udang.

Masalah yang cukup memprihatinkan adalah kematian larva secara massal dalam waktu singkat karena serangan bakteri vibrio bercahaya

") Peneliti pada Loka Penelitian Perikanan Panti Gondol, Bali

*) Tenaga ahli Proyek JICA ATA-379 di Lolitkanta Gondol, Bali 
atau luminescent vibriosis. Terjadinya ledakan populasi mikroorganisme di perairan pantai pada musim-musim tertentu akan lebih memperburuk kondisi, sehingga menimbulkan perubahan lingkungan dan akhirnya kemungkinan akan menyebabkan wabah penyakit. Hal ini merupakan penyebab timbulnya masalah mortalitas pada larva. Fukami et al.(1992 ) menyatakan bahwa terjadinya blooming algae di perairan pantai seringkali menyebabkan kerusakan yang parah bagi perikanan budidaya laut.

Kemampuan untuk mengontrol terjadinya serangan penyakit dan perubahan lingkungan dalam pemeliharaan larva secara intensif, merupakan faktor yang sangat berpengaruh bagi keberhasilan produksi dan kualitas benih. Selama ini cara penanggulangan yang dilakukan adalah dengan desinfeksi air (melalui penyinaran ultra violet, penggunaan chlorin, penyaringan air, dll.), pencucian telur, penggunaan pakan alami yang bersih dan penerapan lingkungan yang higienis (Chamberlain, 1991; Garriques dan Arevalo, 1995).

Dalam upaya mengantisipasi serangan vibrio atau bakteri patogen lainnya, di samping untuk meningkatkan pertumbuhan dan sintasan larva, sudah dikembangkan penggunaan bakteri sebagai probiotik bagi pemeliharaan larva udang dan kepiting. Satu di antaranya adalah bakteri PM-4 yang telah digunakan di Jepang untuk produksi larva kepiting. Demikian pula penggunaan bakteri Vibrio alginoliticus untuk produksi benih udang Penaeus vannamei di Equador. Salah satu prinsip pendekatannya adalah mempertahankan keseimbangan alami bakteri dan mikroorganisme lainnya dalam sistem pemeliharaan larva (Maeda dan Nogami, 1989; Maeda et al., 1992; Maeda, 1994; Maeda dan Liao, 1992; 1994). Penjelasan seperti dinyatakan oleh Garriques dan Arevalo (1995), bahwa banyak teori yang dapat menerangkan peranan probiotik dalam sistem akuakultur, yaitu: (a) semata-mata hanya melakukan kompetisi dengan bakteri patogen; (b) menambah nutrisi dengan menyediakan nutriea esensial; (c) meningkatkan daya cerna dengan mengeluarkan enzim esensial; (d) langsung menyerap bahan organik terlarut; dan (e) memproduksi substansi yang menghambat pertumbuhan bakteri oportunistik patogen.
Hingga kini pemanfaatan bakteri sangat populer dalam upaya mencegah pencemaran dan kerusakan lingkungan perairan, karena bakteri merupakan satu di antara mikroorganisme yang efektif terhadap fisiologis mikroorganisme dan berperanan penting dalam pengaturan pertumbuhan maupun penurunan populasinya (Fukami et al., 1991 ; Fukami et al., 1992"; Fukami et al., $\left.1992^{b}\right)$.

Dengan isolasi, purifikasi dan pengujian serta pengkulturan strain bakteri yang menguntungkan diharapkan dapat diperoleh metode pengontrolan lingkungan pemeliharaan larva secara biologis yang efektif bagi keperluan pembenihan udang. Dengan demikian tingkat sintasan dan pertumbuhan larva dapat diperbaiki dan bahkan ditingkatkan.

\section{BAHAN DAN METODE}

\section{Isolasi Bakteri}

Sampel air laut diencerkan secara bertahap dari 10 hingga 10.000 kali. Dengan volume 0,1 $\mathrm{mL}$ masing-masing suspensi bakteri dibiakkan pada media marine agar dan diinkubasikan selama 24 jam pada suhu $25^{\circ} \mathrm{C}$. Koloni bakteri yang tumbuh dipilih berdasarkan perbedaan morfologi (bentuk, ukuran dan warna) dan dibiakkan lagi pada marine agar yang lain. Masingmasing sampel diisolasi 5-10 koloni. Metode purifikasi ini diulang hingga 4-5 kali, sehingga diperoleh isolat bakteri yang tunggal dan murni. Selanjutnya isolat murni diinkubasikan pada suhu $25^{\circ} \mathrm{C}$ untuk pengujian lebih lanjut.

Vibrio diisolasi dari larva udang dan air pemeliharaannya. Dengan metode yang sama, sampel ditambahkan pada media Thiosulphate Citrate Bile Salt (TCBS) agar. Koloni vibrio yang tumbuh dengan morfologi berbeda diisolasi dengan membiakkan lagi pada media agar yang baru untuk pemurnian koloni. Masing-masing sampel diambil 3-5 koloni. Selanjutnya kultur vibrio yang telah murni diinkubasikan dalam media marine agar pada suhu $25^{\circ} \mathrm{C}$ untuk pengujian lebih lanjut.

\section{Pengujian Daya Hambat Bakteri ter- hadap Pertumbuhan Vibrio}

Masalah utama dalam pembenihan udang adalah kematian larva secara total dalam waktu singkat akibat serangan bakteri vibrio terutama 
vibrio bercahaya. Oleh karena itu, diperlukan pengujian efektivitas daya hambat bakteri terhadap vibrio. Pengujian adanya efek penghambatan dari bakteri terhadap vibrio dilakukan menggunakan Vibriostatic activity test. (Nogami dan Maeda, 1992).

Pengujian diawali dengan menggoreskan dua goresan persegi panjang setiap isolat bakteri yang diperoleh $(4 \mathrm{~cm}$ panjang dan jarak antara goresan $3 \mathrm{~cm}$ ) pada media marine agar. Dengan interval waktu preinkubasi $1 ; 3 ; 6 ; 9$ dan 12 hari kemudian diinokulasi vibrio di antara 2 goresan sebelumnya sepanjang $2 \mathrm{~cm}$. Aktivitas vibriostatik ditentukan melalui pengukuran lebar koloni vibrio. Waktu inkubasi adalah 15 hari. Lebar goresan vibrio akan lebih kecil dibandingkan dengan kontrol (tanpa diuji dengan isolat probiotik), jika isolat probiotik mempunyai kemampuan untuk menekan pertumbuhan vibrio. Isolat yang mempunyai daya hambat tertinggi dengan waktu preinkubasi terpendek kemudian diidentifikasi dengan API-20 E.

\section{Kultur Massal Bakteri}

Isolat bakteri yang mempunyai daya hambat tertinggi selanjutnya dikembangbiakkan dengan mengikuti metode Nogami dan Maeda (1992). Sistem pengkulturan serupa dengan pengkultur. an mikroalgae dan volume inokulum disesuaikan dengan kebutuhan penelitian. Media kultur bakteri mengandung campuran antara bacto peptone, bacto malt-ekstract, bacto yeast-extract dan bacto soytone dengan kadar masing-masing 0,$05 ; 0,1 ; 0,05 ; 0,1 \%$ dalam air laut steril dengan $\mathrm{pH} 7,6$ dan suhu $25^{\circ} \mathrm{C}$.

Isolat murni pada media agar-agar disuspensikan dalam $10 \mathrm{~mL}$ air laut steril dengan jarum ose sebanyak 2,5 $\mathrm{mL}$ suspensi bakteri tersebut diinokulasikan lebih lanjut ke dalam $50 \mathrm{~mL}$ media tumbuh baru yang telah disiapkan dan diinkubasikan selama 48 jam dalam $25^{\circ} \mathrm{C}$. Kepadatan bakteri pada volume ini adalah sekitar $3-5 \times 10^{7}$ cfu (colony forming unit) $/ \mathrm{mL}$. Bakteri yang telah tumbuh dalam $50 \mathrm{~mL}$ media, kemudian diinokulasikan lagi sebanyak $2,5 \mathrm{~mL}$ ke dalam $250 \mathrm{~mL}$ media tumbuh yang baru dan selanjutnya kultur ini diinokulasikan pada media tumbuh baru hingga diperoleh kultur dengan volume $1000 \mathrm{~mL}$. Kepadatan bakteri yang dicapai setelah inkubasi 48 jam adalah $7-8 \times 10^{9} \mathrm{cfu} / \mathrm{mL}$. Selama kultur pada volume besar diperlukan pe- ngocokan (rotary shaking). Dari volume tersebut bakteri sudah dapat digunakan untuk inokulasi dalam media pemeliharaan larva sesuai dengan perlakuan yang diterapkan.

\section{Pematangan Induk dan Pemeliharaan Larva Udang}

Pematangan induk udang dilakukan dalam bak beton bulat volume $8 \mathrm{~m}^{3}$ dan kedalaman air $70 \mathrm{~cm}$. Perbandingan induk jantan dan betina adalah 1:1. Proses pematangan dirangsang dengan ablasi tangkai mata, pemberian intensitas cahaya 2-4 lux dengan 12 jam terang dan 12 jam gelap serta pergantian air $200 \%$ per hari melalui sistem air mengalir.

Dalam waktu tiga hari setelah perangsangan kematangan gonad, induk betina yang sudah matang telur dipindahkan dalam bak kaca serat volume $500 \mathrm{~L}$ untuk dipijahkan. Pada umumnya pemijahan berlangsung pada malam hari dan telur dikoleksi, dicuci serta ditetaskan. Setelah penetasan, nauplii dipindahkan ke dalam 12 bak polikarbonat volume $30 \mathrm{~L}$ yang diletakkan dalam sistem penangas air dengan suhu $29^{\circ} \mathrm{C}$. Air laut untuk pemeliharaan larva disaring dengan filter $0,45 \mu \mathrm{m}$. Kepadatan nauplii 100 ekor/L dan dipelihara hingga stadia PL-1. Nauplii didesinfektasi dengan menggunakan $100 \mathrm{ppm}$ iodin selama 30 menit. Selama penelitian, larva diberi pakan alami C. ceratosporum dengan kepadatan awal $5.000 \mathrm{sel} / \mathrm{mL}$ dan secara bertahap ditingkatkan hingga $50.000 \mathrm{sel} / \mathrm{mL}$ tergantung stadia larva. Dalam penelitian ini diterapkan dua perlakuan, yaitu inokulasi dengan isolat bakteri terpilih dan tanpa inokulasi bakteri (kontrol). Masing-masing perlakuan diulang 6 kali. Biakan bakteri diinokulasikan setiap hari dengan kepadatan $10^{5} \mathrm{cfu} / \mathrm{mL}$ media kultur larva udang selama 8-9 hari dari stadia zoea 1 hingga PL-1. Jumlah bakteri total dan vibrio dalam air pemeliharaan larva diamati sebelum penebaran nauplii.

\section{Pengujian Toksisitas Bakteri terhadap Larva Udang}

Untuk meyakinkan bahwa bakteri uji tidak bersifat toksis terhadap larva udang maka dilakukan pengujian dengan metode perendaman. Perendaman menggunakan tabung erlenmeyer volume $250 \mathrm{~mL}$ yang diisi dengan air laut steril. 
Larva udang yang diuji adalah dari stadia nauplii, zoea, mysis dan pasca larva-1 dengan kepadatan 50 ekor/tabung. Kepadatan biakan bakteri $10^{5} ; 10^{6} ; 10^{7}$; dan 10 cfu/mL untuk masing-masing stadium. Selama pengujian 12 jam diamati apakah terjadi kematian larva udang.

\section{Pengujian Aktivitas Enzim dari Produk Ekstraseluler Bakteri}

Untuk mengetahui aktivitas enzim dari bakteri yang mempunyai kemampuan sebagai probiotik dilakukan pengujian terhadap produk ekstraselulernya. Pengujian mengikuti metode Xu Bing et al., 1996.

Produk ekstraseluler bakteri diuji dengan metode pelat selofan. Selofan steril diletakkan di atas permukaan marine agar dalam cawan petri dan diinokulasi dengan $0,2 \mathrm{~mL}$ biakan bakteri. Lama inkubasi 24 jam pada $25^{\circ} \mathrm{C}$. Bakteri yang tumbuh di permukaan selofan dicuci dengan 4 $\mathrm{mL}$ 0,01 M larutan penyangga fosfat dengan $\mathrm{pH}$ 7,0. Suspensi sel dipusingkan dengan kecepatan $14.000 \mathrm{rpm}$ pada $5^{\circ} \mathrm{C}$ selama 30 menit dan supernatan yang diperoleh difilter secara steril dengan membran filter $0,2 \mu \mathrm{m}$.

Pengujian aktivitas enzim dilakukan dengan metode pelat silinder. Media agar-agar $2 \%$ yang masing-masing mengandung $0,4 \%$ gelatin; $0,4 \%$ kasein; $0,2 \%$ pati; $2,5 \%$ egg yolk; $1,0 \%$ tween 80 ; $2,0 \%$ urea dan $2 \%$ phenol red pada $\mathrm{pH} 7,5$ disiapkan dalam cawan petri, masing-masing untuk menguji adanya aktivitas enzim gelatinase, kasease, amilase, lesitinase, lipase, urease dan khitinase. Larutan produk ektraseluler ditambahkan ke dalam tabung berbentuk silinder yang telah diletakkan di atas permukaan agar tersebut. Lama inkubasi 48 jam pada $35^{\circ} \mathrm{C}$. Pengamatan aktivitas enzim dilakukan dengan menambahkan $5 \% \mathrm{HgCl}_{2}$ pada agar gelatin, $10 \%$ asam trikloroasetat pada agar kasein, lugol iodin pada agar pati (starch) serta pengamatan perubahan zone pada agar.

\section{HASIL DAN PEMBAHASAN}

Dari 273 isolat bakteri yang diperoleh dan telah diuji aktivitas vibriostatiknya dengan masa preinkubasi berbeda, ternyata hanya satu isolat (kode BY-9) yang mempunyai kemampuan untuk menghambat pertumbuhan Vibrio spp. (Tabel 1). Sedangkan isolat lainnya tidak menunjukkan efektivitas penghambatan, yaitu memerlukan waktu preinkubasi panjang dan daya hambat yang rendah. Isolat dengan kode BY-9 (Tabel 4) ternyata termasuk dalam genus Flavimonas (Holt et al., 1994). Berdasarkan pada hasil tersebut, selanjutnya Flavimonas BY-9 digunakan sebagai probiotik dengan mengembangbiakkannya dalam volume besar untuk diinokulasikan dalam pemeliharaan larva udang. Inokulasi bakteri Flavimonas BY-9 dengan kepadatan $10^{5} \mathrm{cfu} / \mathrm{mL}$ menghasilkan pertumbuhan serta sintasan larva yang lebih baik bila dibandingkan dengan kontrol (Gambar 1).

Tabel 1. Aktivitas vibriostatik bakteri Flavimonas BY-9.

Table 1. Vibriostatic activity of Flavimonas BY-9.

\begin{tabular}{cc}
\hline $\begin{array}{c}\text { Waktu preinkubasi (hari) } \\
\text { Preincubation time (days) }\end{array}$ & $\begin{array}{c}\text { Lebar koloni (mm) } \\
\text { Colony width }(\mathrm{mm})\end{array}$ \\
\hline 1 & 3 \\
3 & 2 \\
6 & 2 \\
9 & 2 \\
12 & 2 \\
kontrol (control) & 6 \\
\hline
\end{tabular}

Vibrio diinokulasikan setelah Flavimonas BY-9 dipreinkubasi pada waktu yang berbeda dan diinkubasikan selama 15 hari sebelum diukur lebar koloninya (Vibrio was inoculated after of Flavimonas BY-9 were preincubated for different time and incubated for 15 days before measurement of its colony width) 

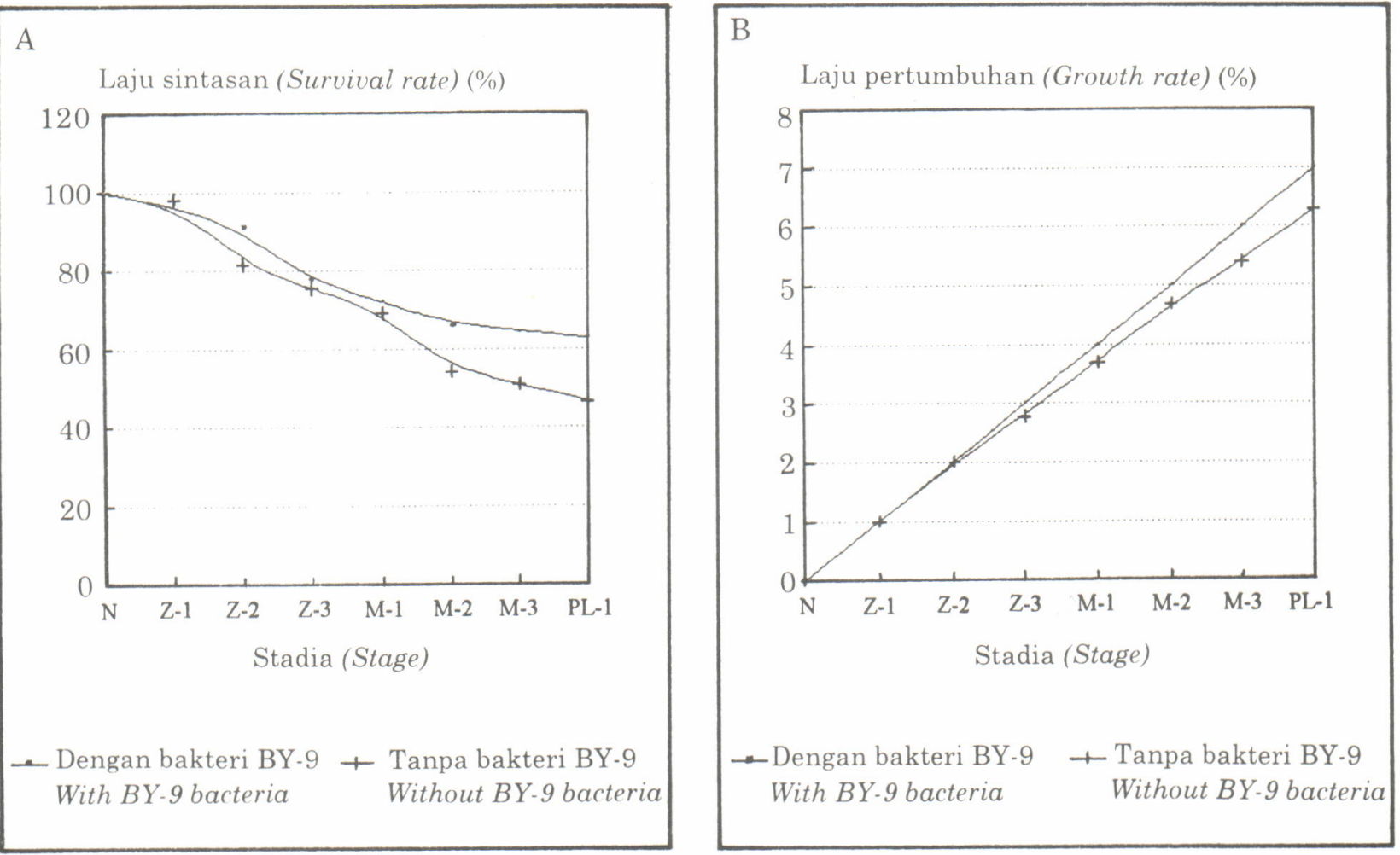

Gambar 1. Sintasan (A) dan laju pertumbuhan (B) larva P. monodon yang dipelihara dengan dan tanpa inokulasi bakteri Flavimonas BY-9.

Figure 1. Survival (A) and growth rate $(B)$ of $P$. monodon larvae reared with and without bacteria Flavimonas BY-9.

Sintasan larva (A) yang diinokulasi bakteri Flavimonas BY-9 terlihat pada Gambar 1. Hal ini menunjukkan bahwa sintasan yang diperoleh lebih tinggi $(62,8 \%)$ dan berbeda nyata $(\mathrm{P}<0,05)$ dibandingkan kontrol (46,6\%). Sintasan larva yang diinokulasi bakteri, secara perlahan-lahan mengalami penurunan dari stadia zoea hingga pascalarva. Sementara itu, pada larva yang tidak diinokulasi bakteri, mortalitas dimulai pada stadia zoea dan secara cepat terjadi pada stadia mysis- 1 hingga pascalarva.

Hal yang sama terjadi pada pertumbuhan larva (B) pada Gambar 1. Terlihat bahwa larva yang dipelihara dengan inokulasi bakteri Flavimonas BY-9, perkembangan stadia hingga stadia pascalarva satu hari lebih cepat daripada kontrol. Laju pertumbuhan larva pada stadia awal (zoea) masih nampak sama. Namun, pada saat mencapai stadia mysis laju pertumbuhan mulai berbeda.
Hasil penelitian menunjukkan ada perbedaan pada sintasan dan pertumbuhan larva di antara dua perlakuan. Adanya perbedaan keragaan ini dimungkinkan karena sel bakteri dapat memperbaiki nutrisi dan kecernaan pada larva udang. Dengan demikian diduga bahwa bakteri meningkatkan status fisiologi dari larva dengan menyediakan sumber nutriea selama pertumbuhan. Dugaan ini dibuktikan dengan pengamatan adanya bakteri dalam saluran pencernaan larva. Melalui pewarnaan dengan acridine orange dan pengamatan di bawah mikroskop epiflourescent ternyata bakteri berada dalam saluran pencernaan larva pada stadia zoea-1 hingga mysis-2, sedangkan pada mysis-3 dan pascalarva, bakteri tidak ditemukan pada saluran pencernaan larva udang.

Bila dilihat dari hasil pengujian aktivitas enzim dari produk ekstraseluler bakteri (Tabel 2) nampaknya ada beberapa enzim yang dapat menstimulasi daya cerna larva udang. 
Tabel 2. Aktivitas enzim dari produk ekstraseluler bakteri Flavimonas BY-9.

Tabel 2. Enzym activity of extracelluler product of Flavimonas BY-9.

\begin{tabular}{lc}
\hline \multicolumn{1}{c}{ Enzim (Enzyme) } & Aktivitas (Activitity) \\
\hline Gelatinase (Gelatinase) & + \\
Amilase (Amylase) & - \\
Kasease (Casease) & + \\
Lipase (Lipase) & + \\
Lesitinase (Lecithinase) & + \\
Khitinase (Chitinase) & - \\
Urease (Urease) & - \\
\hline & \\
$+=$ reaksi positif (reaction positive) \\
$-=$ reaksi negatif (reaction negative)
\end{tabular}

Pengujian terhadap toksisitas bakteri Flavimonas BY-9 menunjukkan bahwa isolat ini tidak bersifat toksis bagi larva udang, karena larva pada stadia nauplii hingga pascalarva-1 tidak mengalami kematian selama pengujian dengan konsentrasi bakteri yang tinggi $\left(10^{8} \mathrm{cfu} / \mathrm{mL}\right)$.

Pengamatan terhadap perlakuan kontrol terlihat bahwa pada stadium zoea, larva terinfeksi vibrio yang ditandai dengan adanya cahaya luminescent pada tubuh larva dalam kondisi gelap. Selain itu pada TCBS agar menunjukkan koloni hijau dan menyala pada media marine agar. Keadaan ini akan menyebabkan penurunan kesehatan dan ketahanan terhadap perubahan lingkungan pemeliharaan dan akhirnya menyebabkan kematian.

Kepadatan total bakteri (A) di dalam air pemeliharaan larva terlihat meningkat hingga $10^{6}$ cfu/ml pada zoea-2 dengan inokulasi bakteri Flavimonas BY-9, tetapi menjadi stabil hingga stadia pascalarva. Sebaliknya, kepadatan total bakteri pada kontrol (A) semakin meningkat pada air pemeliharaan larva. Sedangkan populasi Vibrio spp. (B) dalam bak pemeliharaan larva ternyata cenderung menurun dengan adanya inokulasi bakteri Flavimonas BY-9. Nampaknya, terjadi kompetisi atau penghambatan antara pertumbuhan Flavimonas BY-9 dan Vibrio spp. (Gambar 2). Fenomena tersebut nampaknya sesuai dengan penjelasan yang dinyatakan oleh Garriques dan Arevalo (1995), yang menerangkan tentang peranan probiotik sebagai pengontrol biologis pada akuakultur, yaitu melakukan kompetisi dengan bakteri patogen atau memproduksi substansi penghambat pertumbuhan bakteri oportunistik patogen.

Hasil pemantauan mutu air yang dilakukan pada masing-masing stadium larva tertera pada Tabel 3. Kisaran nilai rata-rata suhu, $\mathrm{pH}$ dan salinitas tidak menunjukkan variasi yang besar. Namun, nitrit $\left(\mathrm{NO}_{2}-\mathrm{N}\right)$ dan total ammonia $\left(\mathrm{NH}_{3}\right.$. $\mathrm{N})$ nampaknya sedikit bervariasi antar perlakuan.

Hasil rata-rata nitrit dan ammonia pada perlakuan inokulasi bakteri relatif menunjukkan nilai yang lebih rendah dibandingkan pada kontrol. Nampaknya penambahan bakteri Flavimonas BY-9 dapat menstimulasi dekomposisi bahan-bahan organik atau detritus dalam bak pemeliharaan larva. Nishijima dan Fukami (1995) melaporkan bahwa strain bakteri Bacillus subtilis tidak hanya menstimulasi pertumbuhan ikan ekor kuning stadia juvenil, tetapi juga mampu mendekomposisi protein dan karbohidrat serta secara kontinyu mengurangi pencemaran bahan organik.

Karakteristik bakteri Flavimonas BY-9 tertera pada Tabel 4. Bakteri tersebut bersifat gram negatif, koloni berwarna kuning, bersifat oksidatif tidak memerlukan substrat glukose untuk pertumbuhannya dan berbentuk batang. 

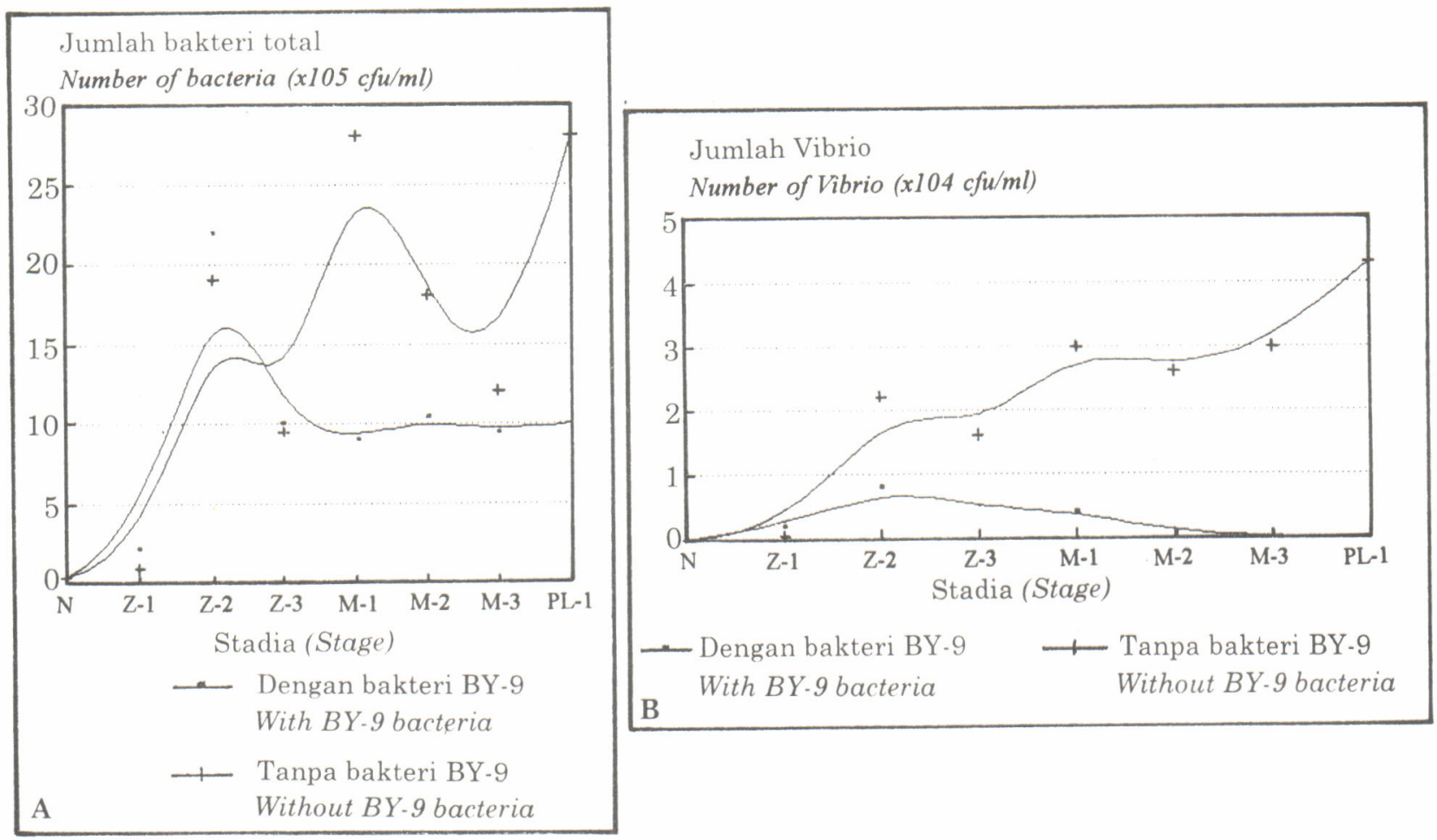

Gambar 2. Pola pertumbuhan total bakteri (A) dan Vibrio spp. (B) dalam air pemeliharaan larva udang P. monodon

Figure 2. Growth patterns of total bacteria (A) and Vibrio spp. (B) in the rearing water of P. monodon.

Tabel 3. Nilai mutu air pemeliharaan larva udang $P$. monodon dengan dan tanpa inokulasi Flavimonas BY-9.

Table 3. Water quality value of rearing water of $P$. monodon larvae with and without inoculation of bacteria Flavimonas BY-9.

\begin{tabular}{|c|c|c|c|c|c|c|}
\hline \multirow[t]{2}{*}{$\begin{array}{l}\text { Peubah } \\
\text { Variables }\end{array}$} & \multicolumn{3}{|c|}{$\begin{array}{l}\text { Dengan inokulasi bakteri } \\
\text { With bacteria inoculation }\end{array}$} & \multicolumn{3}{|c|}{$\begin{array}{c}\text { Tanpa inokulasi bakteri } \\
\text { Without bacteria inoculation }\end{array}$} \\
\hline & Zoea & Mysis & $P L$ & Zoea & Mysis & $P L$ \\
\hline $\begin{array}{l}\text { Suhu (Water Temp.) } \\
\quad{ }^{\circ} \mathrm{C} \\
\text { pagi (morning) } \\
\text { sore (afternoon) }\end{array}$ & $\begin{array}{l}28.5-28.8 \\
29.9-30.2\end{array}$ & $\begin{array}{l}28.5-28.8 \\
29.7-30.1\end{array}$ & $\begin{array}{l}28.5-28.9 \\
29.9-30.6\end{array}$ & $\begin{array}{l}28.4-28.9 \\
29.8-30.1\end{array}$ & $\begin{array}{l}28.2-28.7 \\
29.5-30.2\end{array}$ & $\begin{array}{l}28.4-28.6 \\
29.8-30.1\end{array}$ \\
\hline $\begin{array}{l}\mathrm{pH} \\
\quad \text { pagi (morning) } \\
\text { sore (afternoon) }\end{array}$ & $\begin{array}{l}8.15-8.21 \\
8.27-8.29\end{array}$ & $\begin{array}{l}8.22-8.34 \\
8.27-8.39\end{array}$ & $\begin{array}{l}8.21-8.32 \\
8.27-8.32\end{array}$ & $\begin{array}{l}8.15-8.30 \\
8.27-8.33\end{array}$ & $\begin{array}{l}8.20-8.29 \\
8.30-8.40\end{array}$ & $\begin{array}{l}8.20-8.29 \\
8.30-8.36\end{array}$ \\
\hline $\begin{array}{ll}\text { Salinitas (Salinity) } & \text { (ppt) } \\
\mathrm{NO}_{2}-\mathrm{N} & \text { (ppm) } \\
\mathrm{NH}_{4}-\mathrm{N} & \text { (ppm) }\end{array}$ & $\begin{array}{l}0.010-0.020 \\
0.020-0.030\end{array}$ & $\begin{array}{l}0.015-0.016 \\
0.040-0.050\end{array}$ & $\begin{array}{l}0.033-0.036 \\
0.072-0.096\end{array}$ & $\begin{array}{l}0.031-0.040 \\
0.030-0.040\end{array}$ & $\begin{array}{l}0.017-0.019 \\
0.048-0.054\end{array}$ & $\begin{array}{l}0.031-0.043 \\
0.096-0.163\end{array}$ \\
\hline
\end{tabular}


Tabel 4. Beberapa karakteristik bakteri Flavimonas BY-9.

Table 4. Some characteristics of bacteria Flavimonas BY-9.

\begin{tabular}{lc}
\multicolumn{1}{c}{ Peubah (Variables) } & Karakter (Character) \\
\hline Pigmentasi (Pigmentation) & Kuning (Yellow) \\
Luminescence & - \\
Koloni Melayang (Swarming colonies) & - \\
Reaksi gram (Gram reaction) & - \\
Bentuk (Shape) & Batang (rods) \\
B-Galactosidase & - \\
Arginine dehydrolase & - \\
Lysine decarboxylase & - \\
Pemanfaatan sitrat (Cytrate utilization) & - \\
Produksi H2S (H2S production) & - \\
Urease & - \\
Tryptophane desaminase & - \\
Indole production & - \\
Reaksi V-P (Voges-Proskauer reaction) & - \\
Gelatinase & + \\
Glukose (Glucose) & - \\
Mannitol & - \\
Inositol & - \\
Sorbitol & - \\
Rhamnose & - \\
Sucrose & - \\
Melibiose & - \\
Amygdalin & - \\
Oxabinose & - \\
Produksi NO2 (NO2 production) & - \\
Reduksi gas N2 (Reduction of N2 gas) & - \\
OF-F & - \\
GF-O & - \\
& - \\
&
\end{tabular}

- : Reaksi negatif (Negative reaction)

$+\quad$ Reaksi positif (Positive reaction)

Dengan demikian kemampuan untuk memanipulasi keseimbangan flora bakteri dan ekologi dalam sistem pemeliharaan larva melalui inokulasi bakteri yang menguntungkan merupakan alternatif yang memungkinkan untuk kesinambungan industri perudangan yang lestari di masa datang. 


\section{KESIMPULAN}

Penggunaan bakteri Flavimonas BY-9 dapat meningkatkan pertumbuhan dan sintasan dalam pemeliharaan larva udang windu Penaeus monodon.

Sintasan larva yang diinokulasikan dengan bakteri Flavimonas BY-9 lebih baik $(62,8 \%)$ dibanding tanpa inokulasi $(46,6 \%)$.

\section{DAFTAR PUSTAKA}

Chamberlain, G.W. 1991. Seedstock production. World Aquaculture 22(3):51-57.

Fukami, K.; T. Nishijima; H. Murata; S. Doi and Y. Hata. 1991. Distribution of bacterium influential on the development and the decay of Gymnodinium nagasakiense red tide and their effects on algal growth. Nippon Suisan Gakkaishi, 57 (12): 2321 2326.

Fukami, K.: T. Nishijima and Y. Hata. 1992a . Availability of deep seawater and effects of bacteria isolated from deep seawater on the mass culture of food microalga Chaetoceros ceratosporum. Nippon Suisan Gakkaishi 58(5): 931-936.

Fukami, K.; A. Yuzawa; T. Nishijima; and Y. Hata. $1992^{\mathrm{h}}$. Isolation and properties of bacterium inhibiting the growth of Gymnodinium nagasakiense. Nippon Suisan Gakkaishi 58(6): 1073-1077.

Garriques, D. and G. Arevalo. 1995. An evaluation of the production and use of a live bacterial isolate to manipulate the microbial flora in the commercial production of Penaeus vannamei postlarvae in Equador. p: 53-59. In Browdy and J.S. Hopkins (eds.): Swimming through trouble water. Proceeding of the special session on shrimp farming
Aquaculture '95. World Aquaculture Society, Baton Rouge, Lousiana USA.

Maeda,M. and K. Nogami. 1989. Some aspects of the biocontrolling method in aquaculture. p: 395-398. In Miyachi S., I. Karube and Y. Ishida (eds.): Current topics in marine biotechnology. Japan Soc. Mar. Biotechnol. Tokyo.

Maeda, M.; K. Nogami; and N. Isbhibashi. 1992. Utility of microbial food assemblages for culturing a crab, Portunus iillabarculatus. Bull. Natl. Res. Inst. Aquaculture. 21: 31-38.

Maeda, M. and I.C. Liao. 1992. Effect of bacterial population on the growth of prawn larvae Penaeus monodon. Bull. Natl. Res. Inst. Aquaculture 21: 2529.

Maeda, M. 1994. Biocontrol of the larval rearing biotope in aquaculture. Bull. Natl. Res. Inst. Aquaculture Suppl.1:71-74.

Maeda, M. and I.C. Liao. 1994. Microbial processes in Aquaculture environment and importance for increasing crustacean production. JARQ 28(4): 283 288.

Nishijima, T. and K. Fukami. 1995. Bioremediation of polluted fish farms by a bacterium Bacillus subtilis. Faculty of Agriculture, Kochi University, Japan. 6 p. (In press)

Nogami, K. and M. Maeda. 1992. Bacteria as biocontrol agents for rearing larvae of the crab Portunus trituberculatus. Canadian Journal of Fisheries and Aquatic Science 49(11): 2373-2376.

Xu Bing; J. Weishang and X. Huaishu. 1996. Pathogens and pathogenicity to Penaeus orientalis Kishinouye. Selected Paper on Marine Biotechnology. College of Marine Life Science, Oceon University of Qingdao. p. 229-236. 